and D. George (eds.)

\title{
Larval development of Sabellastarte spectabilis (Grube, 1878) (Polychaeta: Sabellidae) in Hawaiian waters
}

\author{
DAVID R. BYBEE ${ }^{1}$, JULIE H. BAILEY-BROCK ${ }^{2}$ and CLYDE S. TAMARU ${ }^{3}$ \\ ${ }^{1}$ Department of Zoology, University of Hawaii at Manoa, Honolulu, Hawaii, USA. E-mail: bybee@ hawaii.edu \\ ${ }^{2}$ Department of Zoology, University of Hawaii at Manoa, Honolulu, Hawaii, USA. \\ ${ }^{3}$ College Sea Grant Program, University of Hawaii at Manoa, Honolulu, Hawaii, USA.
}

\begin{abstract}
SUMMARY: The sabellid polychaete Sabellastarte spectabilis is common in bays and harbours throughout Hawaii. It has become one of the most harvested marine ornamental species in the State. Collection can be difficult and potentially damaging to the reef community. Understanding the reproduction and life history of this polychaete will benefit the marine ornamental trade by facilitating aquaculture of the species and coral reef conservation by decreasing destructive collecting practices. There is very little known about the biology of this species. Experiments were conducted at the Hawaii Institute of Marine Biology to induce and document spawning and larval development. Oocytes range between 150-200 $\mu \mathrm{m}$ in diameter and sperm have spherical heads. Cell division in fertilized eggs begins approximately twenty minutes after spawning. Developmental stages were documented using light and scanning electron microscopy. Swimming larvae are first seen 7-8 $\mathrm{h}$ after spawning. Larvae have a well-developed prototroch and a less conspicuous neurotroch and metatroch. Two chaetigers develop sequentially on days 4 and 5 and settlement occurs 6-7 days after spawning. Metamorphosis occurs gradually from days 6-8. This is the first reported induction of spawning and description of larval development from fertilized egg to settlement and metamorphosis for this species.
\end{abstract}

Keywords: polychaete reproduction, larval development, Sabellidae

RESUMEN: El desarrollo larvario de Sabellastarte SPECTABills (Grube, 1878) (Polychaeta: Sabellidae) EN HAwAII. - El poliqueto sabélido Sabellastarte spectabilis es común en bahías y puertos de Hawaii. Este sabélido ha llegado a ser una de las especies ornamentales marinas más recolectadas en el estado, pero su recolección es difícil y en muchos casos ocasiona daño a la comunidad arrecifal. Pese a ello, el conocimiento sobre su biología es escaso. El estudio de la reproducción y ciclo de vida de estos sabélidos facilitará su cultivo y beneficiará al mercado de especies ornamentales, a la vez que la diminución de la recogida destructiva se espera pueda contribuir a la conservación de los arrecifes coralinos. En el Hawaii Institute of Marine Biology se realizaron algunos experimentos con la finalidad de inducir y documentar su reproducción y desarrollo larvario. Los huevos miden entre 150-200 $\mu \mathrm{m}$ de diámetro y los espermatozoos presentan cabezas redondas. La división celular de huevos fertilizados comienza aproximadamente 20 minutos después del desove. Los estadios larvarios se documentaron con microscopios de luz y microscopia electrónico de barrido. Las primeras larvas aparecen 7-8 horas después del desove. Las larvas tienen una prototroca muy bien desarrollada y una neurotroca y metatroca menos conspicua. Entre los días 4 y 5 se desarrollan dos setígeros y el reclutamiento ocurrió 6-7 días después del desove. La metamorfosis ocurre gradualmente entre los días 6-8. Este estudio describe por primera vez la inducción del desove y la descripción del desarrollo larvario desde la fertilización del huevo hasta el establecimiento y metamorfosis de la especie.

Palabras clave: reproducción en poliquetos, desarrollo larvario, Sabellidae.

\section{INTRODUCTION}

The conspicuous sabellid polychaete Sabellastarte spectabilis occurs in calm, protected waters throughout Hawaii. Very little is known about the reproduction, life history and distribution patterns of this fanworm (Knight-Jones and Mackie, 2003). Sabellastarte spectabilis has become one of the 
most collected marine ornamentals in the state of Hawaii (Division of Land and Natural Resources, 1994; Walsh et al., 2003) because of its colourful crown and large size. These tubeworms live in cracks and crevices among delicate reef corals making collection difficult. Corals and other components of the reef community are often damaged by collectors. Understanding the reproduction and life history of these polychaetes will help fill a gap in polychaete biology that exists due to the paucity of information about this genus. Moreover, it will benefit the marine ornamental trade by facilitating culture of the species and coral reef conservation by decreasing destructive collecting practices.

Polychaetes are among the most reproductively diverse metazoans (Rouse and Fitzhugh, 1994; Giangrande, 1997; Giangrande et al., 2000; Wilson, 1991). Within the Sabellidae, known reproductive modes include: broadcast spawning, deposition of benthic egg masses, brooding outside the lip of the tube, brooding larvae inside the tube and ovoviviparity (McEuen et al., 1983; Knight-Jones and Bowden, 1984; Rouse and Pleijel 2001). Only one record of reproduction in $S$. spectabilis exists. Individuals were observed broadcast spawning in outdoor water tables at the Hawaii Institute of Marine Biology in October of 1979 (R. Brock in Bailey-Brock, 1987), but very little information was obtained on larval morphology and development. No information was recorded on gamete morphology.

The size and morphology of gametes is often indicative of the reproductive and larval developmental modes in marine invertebrates (Thorson, 1950; Hermans, 1975). It has been observed that when marine invertebrate eggs are less than $180 \mu \mathrm{m}$ in diameter, they usually develop into larvae with a planktonic phase (indirect development), which is generally linked to broadcast spawning (Thorson, 1950). Those with eggs larger than $180 \mu \mathrm{m}$ in diameter tend to develop in situ (direct development) without larval stages, staying within the parent population, as in some brooders and other reproductive modes (Thorson, 1950; Hermans, 1975).

In polychaetes, however, there does not seem to be a very clear relationship between egg size and reproductive or developmental modes (Giangrande, 1997; Pernet et al., 2002). While much work remains to be done before broad generalizations can be made about polychaete reproduction (Giangrande, 1997; Rouse, 1999a) there are some patterns worth noting.
Within the sabellids, sperm types consist of ectaquasperm or ent-aquasperm (Rouse and Jamieson, 1987; Rouse and Fitzhugh, 1994). The former usually with a spherical head and found in broadcast spawners, the latter generally with an elongate head and found in intratubular brooders, but never in broadcasters (Rouse and Fitzhugh, 1994).

In the Sabellidae there is a clear trend showing that small species (which generally produce large eggs) are brooders and large species (usually producing small eggs) are broadcast spawners (Schroeder and Hermans, 1975; McEuen et al., 1983; Rouse and Fitzhugh, 1994). There is also a correlation between reproductive mode and developmental mode. As is the case with most marine invertebrates, in many polychaetes brooding is linked to direct development and broadcast spawning to pelagic (indirect) development.

Direct development entails larvae that develop from embryos into miniature adults without intermediary larval phases required for mid-water survival, and proceed to a benthic existence as seen in brooders such as Amphiglena mediterranea (Rouse and Gambi, 1998). Indirect development is seen in broadcast spawners such as Sabella spallanzanii (Currie et al., 2000). It involves multiple larval phases morphologically very different from the adult and occurs in a planktonic environment where nutritional requirements are met either by external sources (planktotrophic) as seen in sabellariids and some serpulids (Eckelbarger, 1978) or initially by internal sources such as yolk reserves (lecithotrophic). All known sabellids are lecithotrophic (McEuen et al., 1983; Rouse and Fitzhugh, 1994). In the present paper research was focused on the induction of spawning with the goal of confirming reproductive mode, developmental mode and describing gamete morphology and larval developmental stages.

\section{MATERIALS AND METHODS}

Fanworms were collected from nearby reefs surrounding the Hawaii Institute of Marine Biology, Kaneohe Bay, Oahu, Hawaii. Specimens were held in several indoor and outdoor aquaria for observation and monitoring. Each aquarium had a volume of 57 litres and was equipped with a flow-through water system. Gametes were also extracted by dissection from several individuals to observe egg size and sperm morphology with light and scanning electron microscopy (SEM). 


\section{Spawning induction}

Induction trials were conducted during the fall (October-December) as per Bailey-Brock's (1987) spawning observation. To induce spawning, four aquaria were stocked with 15 individuals each and equipped with a continuous flow of seawater at $27^{\circ} \mathrm{C}$ and a salinity of $36 \mathrm{ppt}$. Five worms apiece (at least two females and one male) were selected from two tanks (experimental). A small portion, approximately $1 \mathrm{~cm}$, of the posterior end of each worm was ablated after which worms were placed back into their respective tanks. No ablation took place in the remaining two aquaria (control). Unablated worms were not sexed in either the experimental or control tanks. After spawning, larvae were examined at 3hour intervals under dissecting and compound microscopes until settling occurred. Changes in morphology were documented using digital photo light-microscopy. Sperm cells and larvae were also examined using the scanning electron microscope.

\section{SEM}

For SEM, samples of developing larvae were collected at regular intervals (every 5-6 h) and fixed with $4 \%$ gluteraldehyde in 0.1 molar sodium cacodylate buffer (7.6) with 0.35 molar sucrose. They were washed in 0.1 molar sodium cacodylate buffer with 0.44 molar sucrose. Samples were then post-fixed with $1 \%$ osmium tetroxide in buffer and dehydrated in a graded series of ethanol, critical point dried and mounted on aluminum stubs. They were then sputter-coated with gold palladium and viewed in a Hitatchi S-800 field emission scanning electron microscope at $15 \mathrm{kv}$ accelerating voltage.

\section{RESULTS}

Induction of spawning trials, using different worms in each trial, resulted in two successful spawnings out of three attempts in year one. Year two trials resulted in six successful spawnings out of six attempts using the same methods. Four days after ablation, worms in experimental tanks (including those that had not been ablated) spawned high densities of gametes into the water column. Water in the experimental tanks first became cloudy with sperm. Approximately 5-10 min later, eggs were expelled in spurts, through the top end of the tube. The radioles contracted slightly as the body moved up and down slowly, propelling gametes from the tube with each downward thrust. Some eggs were enveloped in stringy mucus masses, which floated for a time in the water but eventually sank and formed a globular pile on the bottom. Others were released seemingly free of mucus into the water column barely visible as numerous tiny beads. Both
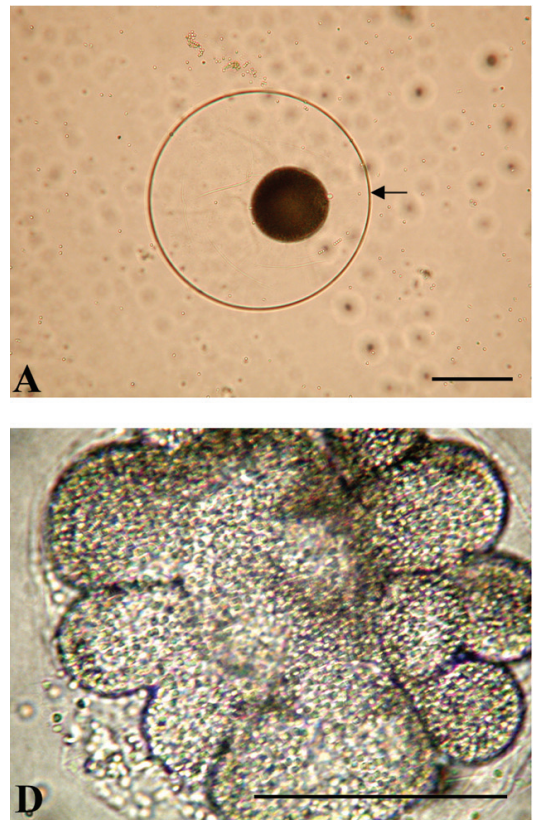
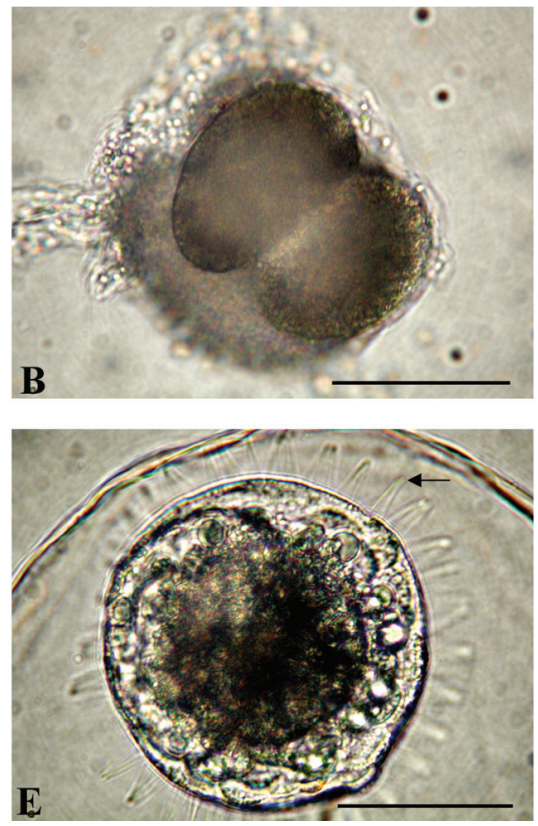
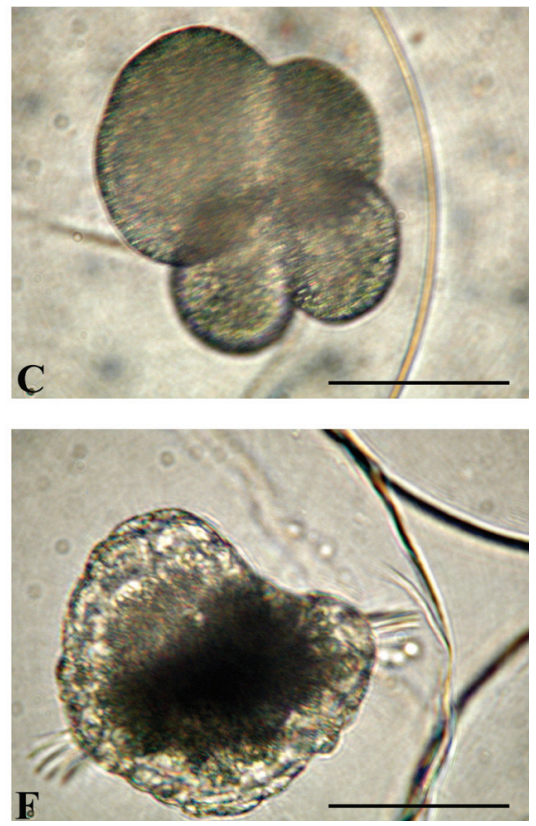

FIG. 1. - A) Recently spawned, fertilized egg of Sabellastarte spectabilis showing fertilization membrane (arrow). Scale bar is $100 \mu \mathrm{m}$. BC) Cleavage is holoblastic and unequal. Scale bars are $50 \mu \mathrm{m}$. D) Morula stage, scale bar is $50 \mu \mathrm{m}$. E) Cilia become visible around the body (arrow) while still encased in fertilization envelope. Scale bar is $50 \mu \mathrm{m}$. F) Body begins to elongate just prior to hatching. Scale bar is $50 \mu \mathrm{m}$. 

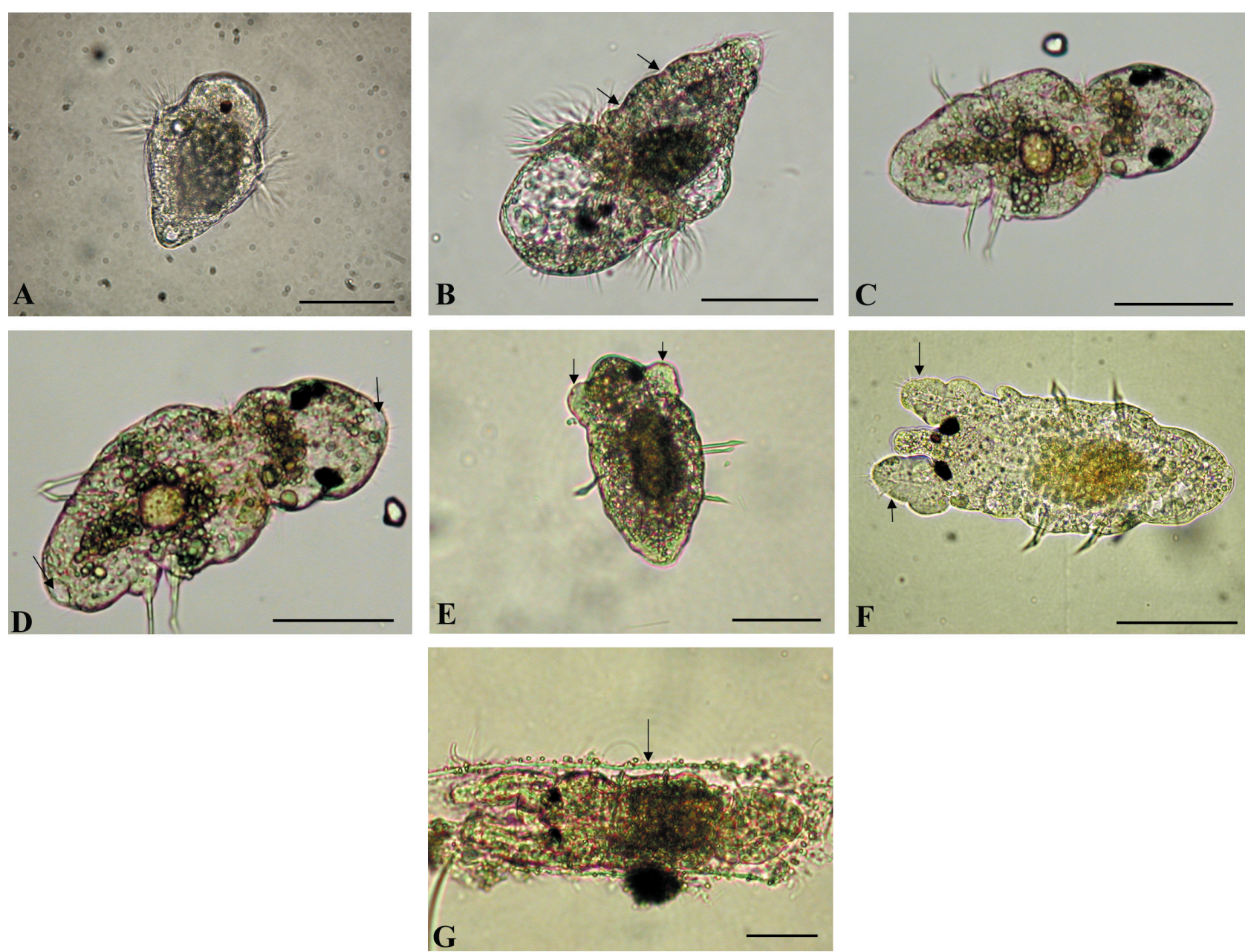

FIG. 2. - All scale bars are equal to $50 \mu \mathrm{m}$. A) Recently hatched trochophore larva. B, body segmentation (arrows) beginning to occur; C, recently settled larva with prototroch almost completely absent and 2 pairs of chaetae; D, head and anal vesicles (arrows) present; E, budding of radioles (arrows) starting to occur; F, radioles well- developed with active cilia (arrows) along the inner margin of each one; G, postmetamorphic individual inside a recently secreted clear mucous tube (arrow).

were opaque and greyish in colour. Eggs were 150$200 \mu \mathrm{m}$ in diameter (smaller eggs may not have been fully mature) and sperm had a rounded nucleus, five spherical mitochondria and a sub-spherical acrosome (ect-aquasperm) (Fig. 3I). No spawning occurred in control tanks.

Developmental stages are summarized in figures 1-3. Fertilization occurred externally, after which an elevated fertilization envelope formed (Fig. 1A). Cleavage was spiral, holoblastic and appeared to be unequal (Fig. 1B-C). Blastulae were visible within 1-2 $\mathrm{h}$ of fertilization. A band of short, rapidly-beating cilia was visible around the midsection of the spherical larva while still inside the egg case (Fig. 1D). The body began to elongate slightly (Fig. 1F) until hatching occurred 7-8 h after spawning.

Trochophore larvae emerged from egg cases with an elongate "top"-shaped body approximately $90 \mu \mathrm{m}$ wide and $120 \mu \mathrm{m}$ long. A prominent pro- totroch encircled the upper midsection separating the episphere and hyposphere (Figs. 2A, 3A-B). Spherical, dark-red eyespots were located dorsolaterally between the prototroch and the anterior end (Fig. 2A). At both ends of the larvae there were distinct, round, clear spots visible, most notably at the rear end (Fig. 2A). Larvae also had a mass of material in the middle of the body, which was visible through the translucent larval epidermis and most likely the remains of yolk (Fig. 2B).

Trochophore larvae developed for 3 days before reaching the metatrochophore stage as evidenced by the formation of visible body segments on day-4, resulting in the first chaetiger (body segment containing chaetae) (Fig. 3C). The anterior region increased in size, developing into a prominent head structure. Eyes and prototroch were still prominent at this stage, as the mass of yolk reserves appeared to be diminishing in size. At this point a single short- 
er band of cilia appeared posterior to the prototroch, presumably a metatroch, but no food groove cilia were observed (Fig. 3F). A less conspicuous neu- rotroch running longitudinally along the ventral side of the body was also visible (Fig. 3D). Though no apical tuft was present, larvae had several thin
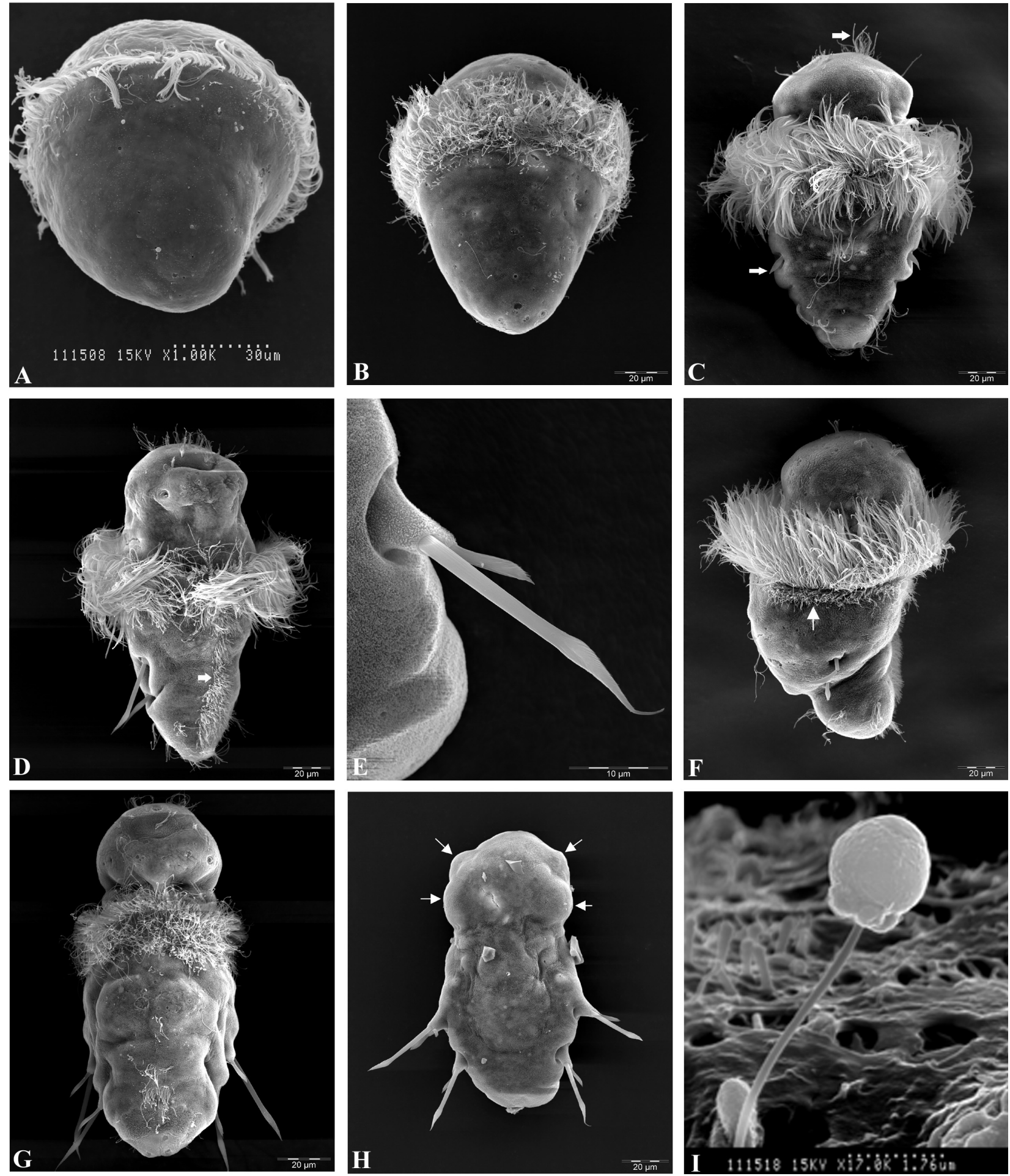

FIG. 3. - A-B, trochophore larvae, 1 and $9 \mathrm{~h}$ after hatching respectively; $\mathrm{C}$, four- day old larva showing body segmentation. The arrows show first chaetiger and thin patches of anterior and posterior cilia; D, five-day old larva with two chaetigers. The arrow shows the neurotroch along the ventral side; E, chaetae; F, prototroch raised exposing the shorter metatroch; G, recently settled larva with a degenerating prototroch; H, day-8 post-metamorphic individual with prototroch completely lost and small nodules (arrows) forming laterally on the prostomium, which will become radioles; I, sperm show spherical nucleus, rounded mitochondria and a low-lying acrosome characteristic of ect-aquasperm. 
patches of cilia at anterior and posterior ends (Figs. 3C-D,F).

Day-5 larvae had two chaetigers, each with a pair of geniculate chaetae (Fig. 3E). Development continued until the prototroch was lost, at which point larvae dropped out of the water column (days 6-7), no longer able to swim, and settled on the bottom (Figs. 2C-F, 3G,H). They crawled around briefly on the substratum before 2-4 small bulges appeared on the prostomium, which quickly developed into radioles (feeding appendages) lined with actively beating cilia (Fig. 2F). Soon thereafter larvae commenced construction of mucous tubes (Fig. 2G), taking on a sedentary life style (days 7 and 8). Mortality after settlement was high, especially for those larvae that settled on the glass. Some individuals settled on air stones increasing their longevity and were visible to the naked eye approximately 20 days after spawning but died nearly three months later at a tube diameter of approximately $1 \mathrm{~mm}$.

\section{DISCUSSION}

Data collected during this study support some of the hypothesized correlations between gamete morphology and reproductive mode and larval development. Egg size is apparently not linked to reproductive mode or larval development in sabellids (Giangrande, 1997) but sperm morphology is. The spherical nucleus, rounded mitochondria and a lowlying, sub-spherical acrosome of $S$. spectabilis are very similar to sperm found in other broadcast spawners of the subfamily Sabellinae such as Sabella spallanzanii and Branchiomma luctuosum (Patti et al., 2003). They fit the ect-aquasperm category composed mostly of broadcast spawners (Rouse and Fitzhugh, 1994). In the present study sperm were extracted long before spawning was observed in the laboratory. These results provided evidence that $S$. spectabilis should be a broadcast spawner in its natural environment, most likely with indirect development.

The previously mentioned correlation between body size and reproductive mode in sabellid polychaetes (large-bodied worms tending to be broadcast spawners) is supported with the results from this study. The spawning of gametes in mucous strings is common among sabellids (Wilson, 1991) although the $1 \mathrm{~m}$-long strings described for some species (Currie et al., 2000) were not observed in $S$. spectabilis, which produced mucous strings 20-25 $\mathrm{cm}$ long.

Using chemical signals to induce and or coordinate spawning is common among many marine invertebrates (Watson et al., 2003). Coelomic contents of nereidid polychaetes have been shown to induce both conspecific and heterospecific spawning activity (Hardege et al., 1998). Ablation of some S. spectabilis individuals may have induced spawning in experimental tanks by releasing a chemical substance from the coelom, which signaled other worms with mature gametes to spawn.

Certain types of environmental stressors such as substantial changes in salinity and temperature have been linked to spawning in polychaetes (Schroeder and Hermans, 1975). It is possible that ablated worms were significantly stressed and may have responded to that stress by spawning, which then triggered others in the tank to spawn as well. Further examination will be required to elucidate the exact spawning mechanisms.

There are a number of developmental variations among polychaete larvae (Fauchald, 1983) but several common stages exist. The unsegmented pearshaped trochophore larva appears first. It is encircled by a band of cilia, the prototroch, which divides the body into an episphere and a hyposphere and serves as the larva's main locomotory organ (Heimler, 1988). The metatrochophore follows the trochophore and is recognizable by the onset of segmentation, elongation of the hyposphere and often, the appearance of larval chaetae. The completion of this stage is marked by the onset of metamorphosis, which often begins with the loss of the prototroch (Heimler, 1988) and may occur either before or after settlement (Pernet et al., 2002). At the close of the metatrochophore stage many species undergo settlement and metamorphosis and take up a benthic existence. Other species have what are known as secondary larvae, which may stay in the plankton for varied amounts of time until a subsequent (final) metamorphosis takes place. Examples of secondary larvae include nectochaetes, which have functional parapodia for swimming, and nectosomes which swim using undulatory body movements (Heimler, 1988).

Some species seem to skip larval stages and hatch as a metatrochophore or nectochaete as seen in the polynoids (Schroeder and Hermans, 1975). Some polychaete larvae have a long pelagic phase while others have a very short one before settlement 
and metamorphosis take place (Giangrande et al., 2000). The only recorded observations of Sabellastarte spectabilis larvae were made by Bailey-Brock (1987). She states that three hours after gametes were spawned fertilized eggs were observed and six hours later a well-developed blastula was evident with some beginning gastrulation until trochophore larvae, greyish in colour with maroon eyespots and a conspicuous prototroch, were visible. Four days later the larvae advanced to the metatrochophore stage. No other information has been found on larval development of this genus.

The trochophore larva of $S$. spectabilis, as observed in this study, is typical of many polychaetes. The prototroch is used for swimming, as in all trochophore larvae. It also functions in particle collection in planktotrophic larvae and even in a few nonfeeding (lecithotrophic) larvae (Pernet, 2003). The metatroch usually functions in concert with the prototroch and a third band of cilia called the food groove in a feeding capacity, often referred to as opposed band feeding (Rouse, 1999b; Pernet, 2003). Since $S$. spectabilis is lecithotrophic and no food groove cilia were observed, the function of the metatroch (if functional at all) is unknown. Possible alternative functions for existing feeding cilia in other lecithotrophic sabellids have been suggested (Pernet, 2003). The neurotroch may play a role in testing the substratum prior to settlement and also has a limited locomotory function in settled larvae before the tube is secreted. The small patches of cilia found at both anterior and posterior ends may have a tactile or sensory function similar to the apical tuft found in other species, but absent in $S$. spectabilis.

It is not known when $S$. spectabilis larvae begin to feed. Polychaetes with small eggs often produce feeding trochophores while those with large eggs may begin to feed at later stages such as the metatrochophore, nectochaete or a recently settled stage (Schroeder and Hermans, 1975). The mass of lumpy material seen inside $S$. spectabilis larvae diminishes as they develop and may, in fact, be yolk reserves used to nourish non-feeding (lecithotrophic) larvae. Since all known sabellids are lecithotrophic ( McEuen, 1983; Rouse and Fitzhugh, 1994) it is assumed that this species holds to that same pattern and that larvae begin to feed just prior to or after settlement. A ciliated mouth is visible under the SEM in specimens that have lost the prototroch and begun to settle. It is not clear, however, if the mouth is present and functional (or if there is a functional gut) prior to settlement but concealed by the dense prototroch. The opening of the anus was not observed in this study.

In many polychaete larvae there are rounded clear spots at posterior and anterior ends referred to as head and anal vesicles (Pernet, 2003) such as the ones observed in $S$. spectabilis larvae. In some errant polychaetes these vesicles occur in areas that give rise to lateral antennae (Heacox, 1980). It is unclear what the function or fate of these structures is in S. spectabilis. The posterior clear spots may be mucus-secreting cells which are frequent in the larval epidermis of some polychaetes (Schroeder and Hermans, 1975) and in this species may be used, along with the ventral shield, to secrete the tube after settlement occurs. The high mortality was probably due to predation by other organisms brought in with the flow-through seawater system and will be further investigated in future studies.

This is the first reported induction of spawning, description of gamete morphology and developmental stages from fertilized egg to larval settlement and metamorphosis in this species. In our opinion it is an important step in the development of technology for artificial propagation of this commercially important fan worm and the beginning of establishing spawning patterns, fecundity and larval development in Sabellastarte spectabilis.

\section{ACKNOWLEDGEMENTS}

This paper is funded in part by a grant/cooperative agreement from the National Oceanic and Atmospheric Administration, Project \# A/AS-1, which is sponsored by the University of Hawaii Sea Grant College Program, SOEST, under Institutional Grant Nos. NA86RG0041 and NA16RG2254 from NOAA Office of Sea Grant, Department of Commerce. The views expressed herein are those of the authors and do not necessarily reflect the views of NOAA or any of its sub agencies, UNIHI-SEAGRANT-JC-01-39. Funding for this work also was provided by the Center for Tropical and Subtropical Aquaculture (CTSA) through Grant numbers 9938500-7399 and 2001-38500-10480 from the USDA/CSREES. Other funding sources include a grant from the PADI Foundation and an Edmondson award from the Zoology Department of the University of Hawaii. We are grateful for the help of 
T. Carvalho and the Biological Electron Microscope Facility at the University of Hawaii. C. Kelly, A. Moriwake, V. Moriwake, B. Alexander and D. Thibault at the Hawaii Institute of Marine Biology (contribution \# 1204) were very generous with their time and equipment. M. Tovar was also very helpful with the Spanish translation. The experiments performed in this study comply with the current laws of the USA.

\section{REFERENCES}

Bailey-Brock, J.H. - 1987. Phylum Annelida. In: D. M. Devaney and L. G. Eldredge (eds.), Reef and Shore Fauna of Hawaii, pp. 218-220, 410, 415-416. Bishop Museum Press, Honolulu, Hawaii.

Currie, D.R., M.A. McArthur and B.F. Cohen. - 2000. Reproduction and distribution of the invasive European fanworm Sabella spallanzanii (Polychaeta: Sabellidae) in Port Phillip Bay, Victoria, Australia. Mar. Biol., 136: 645-656.

Division of Land and Natural Resources, State of Hawaii. - 19861994. Catch Data. Hawaii State Government.

Eckelbarger, K.J. - 1978. Metamorphosis and settlement in the Sabellariidae. In: F.S. Chia and S.A. Rice (eds.), Settlement and metamorphosis of marine invertebrate larvae, pp. 145-164. Elsevier/North-Holland Biomedical Press.

Fauchald, K. - 1983. Life diagram patterns in benthic polychaetes. Proc. Biol. Soc. Wash., 96(1): 160-177.

Giangrande, A. - 1997. Polychaete reproduction patterns life cycles and life histories: an overview. Oceangr. Mar. Biol. Ann. Rev., 35: 323-386.

Giangrande, A., M. Licciano, P. Pagliara and M.C. Gambi. - 2000. Gametogenesis and larval development in Sabella spallanzanii (Polychaeta: Sabellidae) from the Mediterranean Sea. Mar. Biol., 136: 847-861.

Hardege, J.D., C. Muller, M. Beckmann, H.D. Bartels-Hardege and M.G. Bentley. -1998 . Timing of reproduction in marine polychaetes: the role of sex pheremones. Ecoscience, 5: 395-404.

Heacox, A.E. - 1980. Reproduction and larval development of Typosyllis pulchra (Berkeley and Berkeley) (Polychaeta: Syllidae). Pac. Sci., 34: 245-259.

Heimler, W. - 1988. Larvae. In: W. Westheide and C. O. Hermans (eds. ), The Ultrastructure of Polychaeta. Microfauna Marina 4, pp. 353-371. Gustav Fischer Verlag, Stuttgart, New York.

Hermans, C.H. - 1975. Polychaete egg sizes, life histories and phylogeny, Repr. Ecol. Mar. Inv., 9: 201-266.
Knight-Jones, P. and A.S.Y. Mackie. - 2003. A revision of Sabellastarte (Polychaeta: Sabellidae). J. Nat. Hist., 37(19): 2269-2301.

Knight-Jones, P. and N. Bowden. - 1984. Incubation and scissiparity in Sabellidae (Polychaeta). J. mar. biol. Ass. U. K., 64: 809-818.

McEuen F.S., B.L. Wu and F.S. Chia. - 1983. Reproduction and development of Sabella media, a sabellid polychaete with extratubular brooding. Mar. Biol., 76: 301-09.

Patti, F.P., M.C. Gambi, and A. Giangrande. - 2003. A preliminary study on the systematic relationships of Sabellinae (Polychaeta, Sabellidae), based on the C1 domain of the $28 \mathrm{~S}$ rDNA, with discussion of reproductive features. It. J. Zool., 70: 269-278.

Pernet, B. - 2003. Persistent ancestral feeding structures in nonfeeding annelid larvae. Biol. Bull., 205: 295-307.

Pernet, B., P.Y. Qian, G.W. Rouse, C.M. Young and K.J. Eckelbarger. - 2002. Phylum Annelida: Polychaeta. In: C.M. Young (ed.), Atlas of Marine Invertebrate Larvae, pp: 208-243. Academic Press Inc., New York.

Rouse, G.W. - 1999a. Polychaete sperm: phylogenetic and functional considerations. Hydrobiologia, 402: 215-224.

Rouse, G.W. - 1999b. Trochophore concepts: ciliary bands and the evolution of larvae in spiralian metazoa. Biol. J. Linn. Soc., 66: 411-464.

Rouse, G.W. and K. Fitzhugh. - 1994. Broadcast fables: Is external fertilization really primitive: Sex, size and larvae in sabellid polychaetes. Zool. Scr., 23: 273-301.

Rouse, G. W. and M. C. Gambi. - 1998. Evolution of reproductive features and larval development in the genus Amphiglena (Polychaeta: Sabellidae). Mar. Biol., 131:743-753.

Rouse, G.W. and B.G.M. Jamieson. - 1987. An ultrastructural study of the spermatozoa of the polychaetes Eurythoe complanata (Amphinomidae), Clymenella sp. and Micromaldane sp. (Maldanidae), with definition of sperm types in relation to reproductive biology. J. Submicrosc. Cytol., 19: 573-584.

Schroeder, P.C. and C.O. Hermans. - 1975. Annelida: Polychaeta. In: A.C. Geise and J.S. Pearse (eds.), Reproduction of marine invertebrates, pp. 1-169. Academic Press Inc., New York.

Thorson, G. - 1950. Reproductive and larval ecology of marine bottom invertebrates. Biol. Rev., 25: 1-45.

Walsh, W.J., S.P. Cotton, J. Dierking and I.D. Williams. - 2003. The commercial Marine Aquarium Fishery in Hawai'i 19762003. In: A.M. Friedlander (ed.), Status of Hawai'i's coastal fisheries in the new millennium. Proceedings of a Symposium sponsored by the American Fisheries Society, Hawai'i chapter, pp. 132-159. Honolulu, Hawai'i.

Watson, G.J., M.G. Bentley, S.M. Gaudron and J.D. Hardege. 2003. The role of chemical signals in spawning induction of polychaete worms and other marine invertebrates. J. Exp. Mar. Biol. Ecol., 294: 169-187.

Wilson, W.H. - 1991. Sexual reproductive modes in polychaetes: classification and diversity. Bull. Mar. Sci., 48: 500-516.

Received September 15, 2004. Accepted May 11, 2005. 